\title{
Pengaruh Dosis Pemupukan dengan Puktan Granul Terhadap Pertumbuhan dan Uji Kompatibilitas Bibit Tanaman Pangan dan Holtikultura
}

\author{
Catur Rini Sulistyaningsih $^{1)}$ dan Catur Budi Handayani ${ }^{2)}$ \\ ${ }^{1)}$ Program Studi Agribisnis, Fakultas Pertanian, ${ }^{2)}$ Program Studi Teknologi Hasil Pertanian Universitas \\ Veteran Bangun Nusantara Sukoharjo, \\ JI. Letjen Sujono Humardani No. 1 Jombor Sukoharjo, Kode pos 57512, \\ Telp.(0271)593156, Fax. (0271) 591065 \\ Email: caturrinisulistyaningsih@gmail.com
}

\begin{abstract}
ABSTRAK
Penelitian ini bertujuan untuk menguji pupuk organik padat dalam bentuk granul terhadap pertumbuhan bibit tanaman uji (pepaya,kelengkeng, rambutan, jeruk, padi, sorgum dan sawi) dan mengetahui kompatibilitas akar bibit tanaman terhadap pupuk organik. Metode penelitian dibagi dalam 2 tahapan yaitu perkecambahan dan pembibitan. Hasil penelitian ini menunjukkan bahwa berdasarkan uji statistik terhadap hubungan antara pemberian dosis pemupukan terhadap tinggi dan jumlah helai daun pepaya, kelengkeng, rambutan, padi, sorgum, sawi, dan jeruk menunjukkan bahwa pemupukan menggunakan pupuk tani granul pada gradasi 20 gram, 30 gram, dan 40 gram tidak memiliki pengaruh yang signifikan terhadap tinggi tanaman dan jumlah helai daun. Untuk bobot tanaman baik bobot tanaman segar maupun kering tertinggi pada umumnya pada dosis pupuk 40 gram, kecuali tanaman sorgum tertinggi pada dosis 30 gram. Untuk root to shoot ratio tertinggi pada umumnya juga pada dosis pupuk 40 gram, kecuali pada tanaman sorgum tertinggi pada dosis pupuk 40 gram, kecuali pada tanaman sorgum tertinggi pada dosis pupuk 20 gram. Uji kompatibilitas tertinggi pada dosis pupuk 40 gram pada tanaman padi, kelengkeng dan jeruk. Pada dosis 30 gram tertinggi pada tanaman rambutan, dan tertinggi pada dosis 20 gram pada tanaman pepaya dan sawi. Dan untuk tanaman sorgum baik pada dosis 20 gram, 30 gram dan 40 gram kolonisasi $0 \%$.

Kata Kunci : pupuk organik, kompatibilitas, bibit
\end{abstract}

\section{ABSTRACT}

The research has two aims. First is testing organic fertilizer in the form of granule to the seed growth tested plant (papaya, longan, rambutan, orange, rice plant, sorghum and mustard green) Second is knowing the compatibility of the seed plant in organic fertilizer. The result of the research shows that the statistic test to the relation between gifted dosage of fertilizing to the height and the sum of leaves of papaya, longan, rambutan, rice plant, sorghum, orange and mustard greens. Its also shows that the fertilizer usage of puktan granule to the gradation of $20 \mathrm{gr}, 30 \mathrm{gr}$, and $40 \mathrm{gr}$ does not have a significant influence to the height of the plant and the sum of leaves. The highest weight of the dried as well as fresh plant usually a $40 \mathrm{gr}$ dosage. There is an exception for the shorgum plant because its highest dosage is $30 \mathrm{gr}$. The highest root to shoot ratio is usually on the dosage of 40 gr fertilizer, except on the sorghum. It has a dosage of $20 \mathrm{gr}$. The highest compatibility test is on $40 \mathrm{gr}$ for rice plant, logan, and orange. Then the highest dosage of $30 \mathrm{gr}$ belongs to rambutan and papaya, while mustard greens have 20gr. The dosage of sorghum $20 \mathrm{gr}, 30 \mathrm{gr}$, and $40 \mathrm{gr}$ has $0 \%$ colonization.

Keyword: organic fertilizer, compatibility, seed

\section{PENDAHULUAN}

Sebagai negara agraris, Indonesia sangat potensial dalam produksi hasil pertanian, tetapi kemampuan kerja yang cepat dari pupuk kimia berdampak buruk pada kelangsungan produktivitas tanah di kemudian hari. Pemakaian pupuk kimia yang berlebihan, dapat menyebabkan pemadatan tanah, pengerasan, pemasaman dan lain sebagainya. Pemakaian pupuk kimia (anorganik) yang berlebihan dan terus menerus, tanah 
menjadi masam, akibatnya banyak unsur hara yang terikat dan tidak dapat dimobilisir oleh tanaman, kondisi demikian akan berakibat produktivitas tanaman menjadi rendah. Tingginya persentase tanah marjinal dan lahan tidur di Indonesia, dengan kondisi $\mathrm{pH}$ rendah dan atau tinggi (pada tanah berkapur), dapat menghambat pertumbuhan dan produksi tanaman. Indonesia memiliki tanah berkapur (kars) cukup luas, dan kendala kondisi tanah berkapur, persediaan air berlimpah, tetapi jauh dibawah permukaan tanah, yang sulit terjangkau oleh akar tanaman, sehingga penyerapan air oleh akar menjadi penghambat pertumbuhan. Hasil penelitian Suharto (1998) menunjukkan bahwa polutan Amoniak dan Nitrat ditemukan sampai ke muara-muara sungai yang disebabkan oleh pemakaian pupuk kimia yang berlebihan. Solusi masalah tersebut adalah dengan penerapan pertanian organik yaitu mereduksi penggunaan pupuk anorganik menjadi pupuk organik yang ramah lingkungan dan aman bagi kesehatan manusia. Salah satu sumber bahan potensial sebagai pupuk organik adalah kotoran dan urin sapi, fungsi penambahan berbagai jenis starter mikroba adalah untuk memperkaya populasi sehingga membantu dalam daur ulang unsur hara, penyimpanan dan pelepasan untuk tanaman. mikroba yang ditambahkan diantaranya adalah azotobacter, bakteri pelarut fosfat, mikoriza. Pupuk organik mampu menanggulangi stres air, memacu pertumbuhan tanaman, dan menanggulangi terserangnya hama penyakit. Oleh karenanya upaya pemanfaatan pupuk organik dengan sistem fermentasi anaerob, yang ramah lingkungan, dan mendapatkan hasil samping biogas (Mahajoeno dan Chalimah, 2010). Tingginya persentase tanah marjinal di Indonesia, dengan kondisi $\mathrm{pH}$ rendah, dan tanah berkapur, yang mempunyai air berlimpah jauh dibawah tanah, sehingga penyerapan air oleh akar menjadi penghambat pertumbuhan. Kondisi tanah yang memiliki kandungan $\mathrm{Ca}$, Fe dan $\mathrm{Al}$ tinggi, dapat mengikat unsur makronutrien, khususnya Phospat $(P)$, yang dapat menghambat pertumbuhan dan produksi tanaman. Tujuan penambahan biofertilizer adalah untuk memperkaya jumlah koloni bakteri ataupun mikroba yang sudah ada pada urin dan feses sapi sehingga saat diaplikasikan sebagai pupuk organik mampu bekerja lebih baik. Adapun biofertilizer tersebut diantaranya azotobacter yang berfungsi menghasilkan hormon pertumbuhan, meningkatkan pertumbuhan tanaman melalui pasokan nitrogen di udara, pasokan pengatur tumbuh, mengurangi kompetisi dengan mikroba lain dalam menambat nitrogen. Azotobacter memberi pengaruh positif terhadap pertumbuhan tanaman yaitu mempengaruhi perkecambahan benih dan memperbaiki pertumbuhan tanaman (Rahmawati, 2005). Bakteri pelarut fosfat (BPF) merupakan bakteri tanah yang bersifat non patogen dan termasuk dalam katagori bakteri pemacu pertumbuhan tanaman. Bakteri tersebut menghasilkan vitamin dan fitohormon yang dapat memperbaiki pertumbuhan akar tanaman dan meningkatkan serapan hara (Glick, 1995). Bakteri pelarut fosfat merupakan satu-satunya kelompok bakteri yang dapat melarutkan $\mathrm{P}$ yang terjerap permukaan oksida-oksida besi dan almunium sebagai senyawa Fe-P dan Al-P (Hartono, 2000). Bakteri tersebut berperan juga dalam transfer energi, penyusunan protein, koenzim, asam nukleat dan senyawasenyawa metabolik lainnya yang dapat menambah aktivitas penyerapan $\mathrm{P}$ pada tumbuhan yang kekurangan $P$ (Rao, 1994). Beberapa manfaat yang dapat diperoleh tanaman inang dari adanya asosiasi mikoriza adalah sebagai berikut (Rahayu dan Akbar, 2003): Meningkatkan penyerapan unsur hara Tanaman yang bermikoriza biasanya tumbuh lebih baik dari pada yang tidak bermikoriza, dapat meningkatkan penyerapan unsur hara makro dan beberapa unsure hara mikro. Selain itu akar tanaman yang bermikoriza dapat menyerap unsur hara dalam bentuk terikat dan tidak tersedia untuk tanaman 
(Serrano, 1985 dalam Suhardi, 1992 dalam Rahayu dan Akbar, 2003).

Tanaman uji yang digunakan adalah padi, sorgum, pepaya, jeruk, kelengkeng, rambutan dan sawi dipilih karena tanaman tersebut tidak hanya untuk pangan, tapi juga pakan dan industri bioethanol. Tanaman buah rambutan, jeruk, kelengkeng dan pepaya adalah buah yang banyak disukai oleh masyarakat, secara ekonomis bernilai tinggi, akan perlu dikembangkan dan dilestarikan. Oleh karenanya pengujian pupuk digunakan jenis tanaman diatas. Pupuk yang dihasilkan dapat bermanfaat meningkatkan kualitas bibit tanaman, sehingga diharapkan bibit dengan menggunakan pupuk organik yang diperkaya dengan biofertilizer yang menguntungkan dapat ditanam disegala kondisi tanah, sehingga dapat digunakan untuk rehabilitasi tanah lingkungan industri karena topsoilnya telah hilang.

\section{BAHAN DAN METODE}

Pupuk organik hasil penelitian diujikan pengaruhnya terhadap pertumbuhan tanaman pangan, buahbuahan, dan sayuran dengan dagrasi dosis $20 \mathrm{gram} /$ tanaman, $30 \mathrm{gram} /$ tanaman dan 40 gram pertanaman, masing-masing 9 kali ulangan pada tiaptiap tanaman uji.

Bahan yang digunakan adalah Biofertilizer, kotoran ternak, dan urin sapi. Peralatan yang digunakan adalah silo, mesin granule, sekop, cangkul dan cetok. Cara pembuatannya:

a. Menyiapkan bahan baku berupa kotoran ternak sebanyak 5 kuintal, biofertilizer 1 liter.

b. Menyiapkan peralatan.

c. Pelaksanaan fermentasi diruang yang beratap yaitu dengan cara biofertilizer dicampurkan pada bahan kotoran ternak secara homogen selama 1 bulan.

d. Fermentasi tersebut setiap satu minggu sekali diadakan pembalikan dan penyiraman dengan air cukup lembab. e. Pembalikan dilaksanakan 4 kali selama fermentasi.

f. Satu minggu berikutnya pupuk sudah bisa dibongkar dan disaring dengan ayakan pasir.

g. Pupuk yang sudah jadi kemudian di lakukan pengepakan.

Setelah diketahui kualitas yang terkandung dalam pupuk organik (layak untuk digunakan), diujikan pada tanaman target yang telah ditentukan. Metode penelitian tahun kedua dibagi dalam beberapa tahapan yaitu :

\section{Perkecambahan}

Perkecambahan untuk mempersiapkan berbagai bibit tanaman diantaranya :

a. Tanaman pangan (padi dan sorgum)

b. Tanaman buah-buahan (rambutan, jeruk, kelengkeng dan pepaya)

c. Tanaman sayuran (sawi)

\section{Cara Kerja}

a. Biji disterilkan dengan alkohol $70 \% 5$ detik, dicuci dengan air steril sebanyak 3 kali. Selanjutnya di sterilkan dengan Byclean 30\% 1 menit, dicuci dengan air steril 3 kali, selanjutnya biji dikecambahkan

b. Perkecambahan masing-masing biji dilakukan dalam gelas plastik dengan media tanah, pupuk organik dan sekam, dengan perbandingan 1:1:1.

c. Dicatat berapa lama masing-masing biji berkecambah dalam tabel berikut:

Tabel 1. Data Perkecambahan Tanaman

\begin{tabular}{|l|l|c|}
\hline $\begin{array}{c}\text { Jenis } \\
\text { Tanaman }\end{array}$ & Tanaman & $\begin{array}{c}\text { Perkecambahan } \\
\text { (hari) }\end{array}$ \\
\hline Pangan & Padi & 2 \\
\cline { 2 - 3 } & Sorgum & 7 \\
\hline \multirow{2}{*}{$\begin{array}{c}\text { Buah- } \\
\text { buahan }\end{array}$} & Rambutan & 14 \\
\cline { 2 - 3 } & Kelengkeng & 5 \\
\cline { 2 - 3 } & Jeruk & 8 \\
\cline { 2 - 3 } & Pepaya & 7 \\
\hline Sayuran & Sawi & 4 \\
\hline
\end{tabular}

\section{Pembibitan dengan perlakuan dosis pupuk organik}

Setelah biji berkecambah, dengan daun 4 buah, tanaman dipindah dalam polybag dengan perbandingan 1:1:1 (tanah, pupuk organik dan sekam), ditambah dengan pupuk organik granul (dari perlakuan I, II dan III) sebanyak 
masing-masing 20, 30 dan 40 gram, yang selanjutnya disebut pertumbuhan awal $\left(\mathrm{t}_{0}\right)$. Pengukuran pertumbuhan selama 2 bulan dari $t_{0}$, dengan interval waktu pengamatan 10 hari

a. Indikator pertumbuhan yang diukur adalah :

- Panjang tanaman (dari permukaan media hingga ujung tanaman tertinggi

- Jumlah daun, dari $t_{0}$

- Biomasa tanaman dan Shoot Root rasio (pada akhir perlakuan),

b. Desain Percobaan RAL (Rancangan Acak Lengkap) di Green house. Variabel bebas adalah dosis pupuk. Variabel terikat adalah pertumbuhan.

Analisis data dengan Duncan (faktornya adalah dosis pupuk terhadap pertumbuhan bibit tanaman uji). Data tinggi dan jumlah daun yang diperoleh dianalisis menggunakan Analysis of Variance aplikasi SPSS.

Faktor:

$\mathrm{A}=$ Jenis Tanaman

$\mathrm{B}=$ Dosis Pupuk

Tabel 2. Data Perlakuan

\begin{tabular}{|c|c|c|c|}
\hline$A$ & \multicolumn{3}{|c|}{ Dosis Pupuk } \\
\hline B & $20 \mathrm{gr}$ & $30 \mathrm{gr}$ & $40 \mathrm{gr}$ \\
\hline Pepaya & A1B1 & A1B2 & A1B3 \\
\hline Kelengkeng & $\mathrm{A} 2 \mathrm{BI}$ & A2B2 & A2B3 \\
\hline Rambutan & A3BI & A3B2 & A3B3 \\
\hline Padi & A4BI & A4B2 & A4B3 \\
\hline Sorgum & A5BI & A5B2 & A5B3 \\
\hline Sawi & $\mathrm{A} 6 \mathrm{BI}$ & A6B2 & A6B3 \\
\hline Jeruk & A7BI & A7B2 & A7B3 \\
\hline
\end{tabular}

Uji Kompatibilitas pupuk organik terhadap akar tanaman target

Uji kompatibilitas yang dilakukan terhadap akar tanaman target menggunakan metode histologis, dengan pewarnaan eosin dan Tryplnd blue, modifikasi (Chalimah 2006). Setelah dilakukan proses histologis selanjutnya diamati persentase kolonisasi pada akar dengan rumus sebagai berikut:

\footnotetext{
Kolonisasi (\%)

$=\frac{\text { Banyaknya kolonisasi dalam bidang pandang }}{\text { Jumlah total bidang pandang yang diamati }} \times 100$
}

\section{HASIL DAN PEMBAHASAN}

Dari alur penelitian didapat hasil sebagai berikut :

\section{Pengaruh Dosis Pemupukan pada Tanaman Pepaya}

Tabel 3. Pengaruh Dosis Pemupukan Pepaya

\begin{tabular}{|c|c|c|}
\hline $\begin{array}{c}\text { Dosis } \\
\text { Tanaman }\end{array}$ & $\begin{array}{c}\text { Tinggi } \\
\text { Tanaman }\end{array}$ & $\begin{array}{c}\text { Jumlah } \\
\text { Daun }\end{array}$ \\
\hline 20 gram & $60,397 \pm 25,53$ & $11,62 \pm 2,97$ \\
\hline 30 gram & $59,302 \pm 28,06$ & $12,67 \pm 3,54$ \\
\hline 40 gram & $65,905 \pm 27,60$ & $14,75 \pm 13,23$ \\
\hline
\end{tabular}

1. Dosis pemupukan terhadap tinggi tanaman

Hasil uji Anova antara dosis pemupukan dan dan tinggi tanaman pepaya diperoleh nilai signifikansi 0.343 sehingga hubungan keduanya tidak signifikan (> 0.05). Sehingga dapat disimpulkan bahwa dosis pemupukan pada gradasi 20 gram, 30 gram, dan 40 gram dengan puktan granul tidak memiliki pengaruh yang signifikan terhadap tinggi tanaman pepaya.

2. Dosis pemupukan terhadap jumlah daun

Hasil uji Anova antara dosis pemupukan dan dan jumlah daun tanaman pepaya diperoleh nilai signifikansi 0.092 sehingga hubungan keduanya tidak signifikan ( $>0.05$ ). Sehingga dapat disimpulkan bahwa dosis pemupukan pada gradasi 20 gram, 30 gram, dan 40 gram dengan puktan granul tidak memiliki pengaruh yang signifikan terhadap jumlah duan tanaman pepaya.

Pengaruh Dosis Pemupukan terhadap Tanaman Kelengkeng

Tabel 4. Data Pengaruh Dosis Pemupukan Kelengkeng

\begin{tabular}{|c|c|c|}
\hline $\begin{array}{c}\text { Dosis } \\
\text { Tanaman }\end{array}$ & $\begin{array}{c}\text { Tinggi } \\
\text { Tanaman }\end{array}$ & $\begin{array}{c}\text { Jumlah } \\
\text { Daun }\end{array}$ \\
\hline 20 gram & $13,302 \pm 5,399$ & $11,62 \pm 2,97$ \\
\hline 30 gram & $14,206 \pm 5,789$ & $12,67 \pm 3,54$ \\
\hline 40 gram & $13,81 \pm 5,808$ & $14,75 \pm 13,23$ \\
\hline
\end{tabular}

1. Dosis pemupukan terhadap tinggi tanaman 
Hasil uji Anova antara dosis pemupukan dan dan tinggi tanaman kelengkeng diperoleh nilai signifikansi 0.669 sehingga hubungan keduanya tidak signifikan (> 0.05 ). Sehingga dapat disimpulkan bahwa dosis pemupukan pada gradasi 20 gram, 30 gram, dan 40 gram dengan puktan granul tidak memiliki pengaruh yang signifikan terhadap tinggi tanaman kelengkeng.

2. Dosis pemupukan terhadap jumlah daun

Hasil uji Anova antara dosis pemupukan dan dan jumlah daun tanaman kelengkeng diperoleh nilai signifikansi 0.457 sehingga hubungan keduanya dikatakan tidak signifikan ( $>0.05)$. Sehingga dapat disimpulkan bahwa dosis pemupukan pada gradasi 20 gram, 30 gram, dan 40 gram dengan puktan granul tidak memiliki pengaruh yang signifikan terhadap jumlah duan tanaman kelengkeng.

\section{Pengaruh Dosis Pemupukan terhadap Tanaman Rambutan}

Tabel 5. Data Pengaruh Dosis Pemupukan Rambutan

\begin{tabular}{|c|c|c|}
\hline $\begin{array}{c}\text { Dosis } \\
\text { Tanaman }\end{array}$ & $\begin{array}{c}\text { Tinggi } \\
\text { Tanaman }\end{array}$ & $\begin{array}{c}\text { Jumlah } \\
\text { Daun }\end{array}$ \\
\hline 20 gram & $27,746 \pm 10,459$ & $4,349 \pm 1,22$ \\
\hline 30 gram & $25,143 \pm 9,119$ & $4,269 \pm 1,194$ \\
\hline 40 gram & $27,079 \pm 11,283$ & $4,286 \pm 1,21$ \\
\hline
\end{tabular}

1. Dosis pemupukan terhadap tinggi tanaman

Hasil uji Anova antara dosis pemupukan dan dan tinggi tanaman rambutan diperoleh nilai signifikansi 0.342 maka hubungan keduanya dikatakan tidak signifikan ( $>$ 0.05). Sehingga dapat disimpulkan bahwa dosis pemupukan pada gradasi 20 gram, 30 gram, dan 40 gram dengan puktan granul tidak memiliki pengaruh yang signifikan terhadap tinggi tanaman rambutan.

2. Dosis pemupukan terhadap jumlah daun

Hasil uji Anova antara dosis pemupukan dan dan jumlah daun tanaman kelengkeng diperoleh nilai signifikansi 0.927 maka hubungan keduanya dikatakan tidak signifikan ( $>0.05)$. Sehingga dapat disimpulkan bahwa dosis pemupukan pada gradasi 20 gram, 30 gram, dan 40 gram menggunakan puktan granul tidak memiliki pengaruh yang signifikan terhadap jumlah helai duan pada tanaman rambutan.

\section{Pengaruh Dosis Pemupukan terhadap Tanaman Padi}

Tabel 6. Data Pengaruh Dosis Pemupukan Tanaman Padi

\begin{tabular}{|c|c|c|}
\hline $\begin{array}{c}\text { Dosis } \\
\text { Tanaman }\end{array}$ & $\begin{array}{c}\text { Tinggi } \\
\text { Tanaman }\end{array}$ & $\begin{array}{c}\text { Jumlah } \\
\text { Daun }\end{array}$ \\
\hline 20 gram & $71,064 \pm 32,701$ & $5,254 \pm 1,694$ \\
\hline 30 gram & $71,794 \pm 32,079$ & $5,492 \pm 1,848$ \\
\hline 40 gram & $77,714 \pm 32,924$ & $5,254 \pm 1,502$ \\
\hline
\end{tabular}

1. Dosis pemupukan terhadap tinggi tanaman

Hasil uji Anova antara dosis pemupukan dan dan tinggi tanaman padi diperoleh nilai signifikansi 0.455 maka hubungan keduanya dikatakan tidak signifikan (> 0.05). Sehingga dapat disimpulkan bahwa dosis pemupukan pada gradasi 20 gram, 30 gram, dan 40 gram menggunakan puktan granul tidak memiliki pengaruh yang signifikan terhadap perbedaan tinggi tanaman padi.

2. Dosis pemupukan terhadap jumlah daun

Hasil uji Anova antara dosis pemupukan dan dan jumlah daun tanaman padi diperoleh nilai signifikansi 0.659 maka hubungan keduanya dikatakan tidak signifikan (> 0.05). Sehingga dapat disimpulkan bahwa dosis pemupukan pada gradasi 20 gram, 30 gram, dan 40 gram menggunakan puktan granul tidak memiliki pengaruh yang signifikan terhadap perbedaan jumlah helai duan pada tanaman padi.

\section{Pengaruh Dosis Pemupukan terhadap Tanaman Sorgum}

Tabel 7. Data Pengaruh Dosis

Pemupukan Sorgum

\begin{tabular}{|c|c|c|}
\hline $\begin{array}{c}\text { Dosis } \\
\text { Tanaman }\end{array}$ & Tinggi Tanaman & $\begin{array}{c}\text { Jumlah } \\
\text { Daun }\end{array}$ \\
\hline 20 gram & $125,873 \pm 58,272$ & $7,809 \pm 2,306$ \\
\hline 30 gram & $127,714 \pm 58,986$ & $7,984 \pm 2,181$ \\
\hline 40 gram & $124,413 \pm 53,805$ & $8,111 \pm 1,924$ \\
\hline
\end{tabular}


1. Dosis pemupukan terhadap tinggi tanaman

Hasil uji Anova antara dosis pemupukan dan dan tinggi tanaman Sorgum diperoleh nilai signifikansi 0.948 maka hubungan keduanya dikatakan tidak signifikan (> 0.05). Sehingga dapat disimpulkan bahwa dosis pemupukan pada gradasi 20 gram, 30 gram, dan 40 gram menggunakan puktan granul tidak memiliki pengaruh yang signifikan terhadap perbedaan tinggi tanaman sorgum.

2. Dosis pemupukan terhadap jumlah daun

Hasil uji Anova antara dosis pemupukan dan jumlah helai daun tanaman sorgum diperoleh nilai signifikansi 0.948 maka hubungan keduanya dikatakan tidak signifikan (> 0.05). Sehingga dapat disimpulkan bahwa dosis pemberian pupuk pada gradasi 20 gram, 30 gram, dan 40 gram menggunakan puktan granul tidak memiliki pengaruh yang signifikan terhadap perbedaan jumlah helai duan pada tanaman sorgum.

\section{Pengaruh Dosis Pemupukan terhadap Tanaman Sawi}

Tabel 8. Data Pengaruh Dosis Pemupukan Tanaman Sawi

\begin{tabular}{|c|c|c|}
\hline $\begin{array}{c}\text { Dosis } \\
\text { Tanaman }\end{array}$ & Tinggi Tanaman & $\begin{array}{c}\text { Jumlah } \\
\text { Daun }\end{array}$ \\
\hline 20 gram & $31.524 \pm 18.998$ & $5.881 \pm 2.002$ \\
\hline 30 gram & $33.69 \pm 20.769$ & $5.786 \pm 2.054$ \\
\hline 40 gram & $36.619 \pm 20.613$ & $6.024 \pm 2.404$ \\
\hline
\end{tabular}

1. Dosis pemupukan terhadap tinggi tanaman

Hasil uji Anova antara dosis pemupukan dan dan tinggi tanaman sawi diperoleh nilai signifikansi 0.510 maka hubungan keduanya dikatakan tidak signifikan (> 0.05). Sehingga dapat disimpulkan bahwa dosis pemupukan pada gradasi 20 gram, 30 gram, dan 40 gram menggunakan puktan granul tidak memiliki pengaruh yang signifikan terhadap terhadap perbedaan tinggi tanaman sorgum.

2. Dosis pemupukan terhadap jumlah daun

Hasil uji Anova antara dosis pemupukan dan jumlah helai daun tanaman sawi diperoleh nilai signifikansi 0.879 maka hubungan keduanya dikatakan tidak signifikan (> 0.05). Sehingga dapat disimpulkan bahwa dosis pemberian pupuk pada gradasi 20 gram, 30 gram, dan 40 gram menggunakan puktan granul tidak memiliki pengaruh yang signifikan terhadap perbedaan jumlah helai duan pada tanaman sawi.

\section{Pengaruh Dosis Pemupukan terhadap Tanaman Jeruk}

Tabel 9. Data Pengaruh Dosis Pemupukan Tanaman Jeruk

\begin{tabular}{|c|c|c|}
\hline $\begin{array}{c}\text { Dosis } \\
\text { Tanaman }\end{array}$ & $\begin{array}{c}\text { Tinggi } \\
\text { Tanaman }\end{array}$ & $\begin{array}{c}\text { Jumlah } \\
\text { Daun }\end{array}$ \\
\hline 20 gram & $10,921 \pm 5,052$ & $8,175 \pm 3,494$ \\
\hline 30 gram & $10 \pm 4,418$ & $7,667 \pm 2,962$ \\
\hline 40 gram & $11,476 \pm 4,809$ & $8,037 \pm 2,924$ \\
\hline
\end{tabular}

1. Dosis pemupukan terhadap tinggi tanaman

Hasil uji Anova antara dosis pemupukan dan dan tinggi tanaman jeruk diperoleh nilai signifikansi 0.217 maka hubungan keduanya dikatakan tidak signifikan (> 0.05). Sehingga dapat disimpulkan bahwa dosis pemupukan pada gradasi 20 gram, 30 gram, dan 40 gram menggunakan puktan granul tidak memiliki pengaruh yang signifikan terhadap terhadap perbedaan tinggi tanaman jeruk.

2. Dosis pemupukan terhadap jumlah daun

Hasil uji Anova antara dosis pemupukan dan jumlah helai daun tanaman jeruk diperoleh nilai signifikansi 0.645 maka hubungan keduanya dikatakan tidak signifikan (> 0.05). Sehingga dapat disimpulkan bahwa dosis pemberian pupuk pada gradasi 20 gram, 30 gram, dan 40 gram menggunakan puktan granul tidak memiliki pengaruh yang signifikan terhadap perbedaan jumlah helai duan pada tanaman jeruk.

Berdasarkan uji statistik terhadap hubungan antara pemberian dosis pemupukan terhadap tinggi dan jumlah helai daun tanaman pepaya, kelengkeng, rambutan, padi, sorgum, sawi dan jeruk menunjukkan bahwa pemupukan menggunkan puktan granul pada gradasi 20 gram, 30 gram, dan 40 gram tidak 
memiliki pengaruh yang signifikan terhadap tinggi tanaman dan jumlah helai daun. Hal ini disebabkan kualitas pupuk sudah sesuai dengan standar kepmentan no. 28 sehingga gradasi pupuk 20 gram, 30 gram, dan 40 gram tidak berpengaruh terhadap tanaman pangan dan non pangan untuk tinggi tanaman dan jumlah daun.

\section{Uji Kompatibilitas}

Hasil uji kompatibilitas pada bibit tanaman pangan (padi dan sorgum) dan bibit tanaman holtikultura (rambutan, jeruk, kelengkeng, pepaya, dan sawi) dengan menggunakan metode histologis, dengan pewarnaan eosin dan trypand blue, modifikasi.Tabel 10. Hasil Analisis Uji Kompatibilitas.

Tabel 10. Hasil Analisis Uji Kompatibilitas

\begin{tabular}{|c|c|c|c|c|c|c|}
\hline $\begin{array}{l}\text { Jenis } \\
\text { Tanaman }\end{array}$ & $\begin{array}{c}\text { Periakuan } \\
\text { pupulk } \\
\text { (gr) }\end{array}$ & $\begin{array}{c}\text { Bobot } \\
\text { Tanaman } \\
\text { segar (gr) }\end{array}$ & $\begin{array}{c}\text { Bobot } \\
\text { Tanaman } \\
\text { Kering } \\
\text { konstan } \\
\text { (gr) }\end{array}$ & $\begin{array}{c}\text { Kadar air } \\
\text { (96) }\end{array}$ & $\begin{array}{l}\text { Root to } \\
\text { Shoot } \\
\text { Ratio }\end{array}$ & Ket \\
\hline \multirow{3}{*}{ Padi } & 20 & 39.525 & 7.316 & 81.490 & 0.314 & \multirow{21}{*}{$\begin{array}{c}\text { Menggunalkar } \\
\text { metode } \\
\text { pengamatan } \\
\text { grafimetri }\end{array}$} \\
\hline & 30 & 48.029 & 11.621 & 75.804 & 0.229 & \\
\hline & 40 & 136.225 & 30.568 & 77.561 & 0.351 & \\
\hline \multirow{3}{*}{ Sorgum } & 20 & 286.773 & 57.336 & 78.667 & 0.172 & \\
\hline & 30 & 349.903 & 82.299 & 76.479 & 0.151 & \\
\hline & 40 & 212.003 & 62.367 & 70.582 & 0.151 & \\
\hline \multirow{3}{*}{ Saswi } & 20 & 21.799 & 1.657 & 92.399 & 0.119 & \\
\hline & 30 & 26.453 & 1.551 & 94.137 & 0.076 & \\
\hline & 40 & 48.806 & 2.691 & 94.486 & 0.044 & \\
\hline \multirow{3}{*}{ Pepsya } & 20 & 156.772 & 16.499 & 89.476 & 0.156 & \\
\hline & 30 & 136.847 & 13.399 & 90.209 & 0.222 & \\
\hline & 40 & 181.768 & 18.803 & 89.476 & 0.227 & \\
\hline \multirow{3}{*}{ Kelengkeng } & 20 & 39.361 & 19.429 & 50.640 & 0.329 & \\
\hline & 30 & 56.140 & 23.388 & 58.340 & 0.285 & \\
\hline & 40 & 68.607 & 30.001 & 56.271 & 0.346 & \\
\hline \multirow{3}{*}{ Rambutan } & 20 & 23.367 & 7.417 & 68.259 & 0.322 & \\
\hline & 30 & 17.612 & 5.678 & 67.755 & 0.356 & \\
\hline & 40 & 26.783 & 8.335 & 68.879 & 0.345 & \\
\hline \multirow{3}{*}{ Jerulk } & 20 & 5.276 & 1.373 & 73.976 & 0.396 & \\
\hline & 30 & 4.672 & 1.128 & 75.856 & 0.396 & \\
\hline & 40 & 5.774 & 1.430 & 75.234 & 0.434 & \\
\hline
\end{tabular}

Dari hasil pengamatan uji kompatibilitas hasil tertinggi pada dosis pemupukan 20 gr yaitu tanaman sawi dan pepaya $(4,00 \%$ dan $17,39 \%)$. Pada dosis pemupukan $30 \mathrm{gr}$ yaitu tanaman rambutan $(5,55 \%)$ dan pada dosis pemupukan 40 gr yaitu padi, kelengkeng, dan jeruk $(4,17 \%, 4,76 \%$, dan $23,81 \%)$. Semakin tinggi persen koloni, menunjukkan yang terinferksi semakin banyak karena spora yang masuk ke jaringan tanaman (akar tanaman) semakin banyak, sehingga unsur yang terserap semakin banyak.

\section{KESIMPULAN}

Berdasarkan uji statistik terhadap hubungan antara pemberian dosis pemupukan terhadap tinggi dan jumlah helai daun tanaman pepaya, kelengkeng, rambutan, padi, sorgum, sawi dan jeruk menunjukkan bahwa pemupukan menggunkan puktan granul pada gradasi 20 gram, 30 gram, dan 40 gram tidak memiliki pengaruh yang signifikan terhadap tinggi tanaman dan jumlah helai daun. Hal ini disebabkan kualitas pupuk sudah sesuai dengan standar kepmentan no. 28 sehingga gradasi pupuk 20 gram, 30 gram, dan 40 gram tidak berpengaruh terhadap tanaman pangan dan non pangan untuk tinggi tanaman dan jumlah daun.

Dari hasil analisis biomasa tanaman padi tertinggi pada dosis pemupukan $40 \mathrm{gr}(0,351)$, sorgum tertinggi pada dosis pemupukan $20 \mathrm{gr}$ $(0,172)$, sawi tertinggi pada dosis pemupukan $20 \mathrm{gr}(0,151)$, pepaya tertinggi pada dosis pemupukan $40 \mathrm{gr}$ $(0,227)$, kelengkeng tertinggi pada dosis pemupukan $40 \mathrm{gr}(0,346)$, rambutan tertinggi pada dosis pemupukan $30 \mathrm{gr}$ $(0,356)$, dan jeruk tertinggi pada dosis pemupukan $40 \mathrm{gr}(0,434)$.

Dari hasil uji kompatibilitas tertinggi pada dosis pemupukan $20 \mathrm{gr}$ yaitu tanaman sawi dan pepaya $(4,00 \%$ dan $17,39 \%$ ). Pada dosis pemupukan 30 gr yaitu tanaman rambutan $(5,55 \%)$ dan pada dosis pemupukan $40 \mathrm{gr}$ yaitu padi, kelengkeng, dan jeruk $(4,17 \%, 4,76 \%$, dan $23,81 \%$ ).

\section{UCAPAN TERIMA KASIH}

Disampaikan terima kasih banyak kepada Dirjen DIKTI yang telah memberikan bantuan dana penelitian melalui dana penelitian program Hibah Bersaing Tahun 2013, dan mahasiswa yang terlibat penelitian ini.

\section{DAFTAR PUSTAKA}

Atmaja, I Wayan Dana. 2001. Bioteknologi Tanah (Ringkasan Kuliah). Jurusan Tanah Fakultas Pertanian Universitas Udayana. Denpasar 
Sulistyaningsih \& Handayani. 2017

Chalimah S 2007. Pemanfaatan teknologi in vivo untuk perkembangan Gigaspora margarita dan Acaulospora tuberculata. Biodiversitas 7: 3-5. UNS

Chalimah dan Mahajoeno 2009. Eksplorasi CMA dilahan kering dan berkapur daerah Kabupaten Tuban. Laporan Hibah Fundamental , yang didesiminasikan dalam seminar nasional ITS 2010

Glick, BR. 1995. The enhancement of plant growth by free living bacteria. Canadian Journal Microbiology 41: 109-117.

Imelda M, Sudarnowati E, Ermayanti TM, Bachtiar AS, Yunita E, Priyadi D. 1995. Perbanyakan klonal in vitro. Penelitian tanaman Bioteknologi tanaman.

http/catalog.pdii.lipi.go.id/indeks.

Php/search

chatalog/donload/7447/7447/pdf

Mahajoeno dan Chalimah 2010. Produksi pupuk organic secara anaerob dan aerob dari berbagai limbah organic, laporan Riset sub hibah Pasca (Belum dipublikasi)

Octavitani, N. 2009. Pemanfaatan Cendawan Mikoriza Arbuscular (CMA) sebagai Pupuk Hayati untuk
Meningkatkan Produksi Pertanian. Jurnal Lingkungan Hidup.uwityangyoyo.wordpress.co m. Diakses Tanggal 20 Februari 2011 Pukul 19.09 WIB.

Rahayu, Novi., dan Ade Kusuma Akbar. 2003. Pemanfaatan Mikoriza dan Bahan Organik Dalam Rangka Reklamasi Lahan Pasca Penambangan. Karya Tulis IImiah. Fakultas Pertanian Universitas Tanjungpura. Pontianak.

Rao, N. S. S. 1994. Mikroorganisme Tanah dan Pertumbuhan Tanaman. UI - Press. Jakarta.

Situmorang, J. 2000. Mikropropagasi Kayu Gaharu (Aquilaria spp.) asal Riau serta Identifikasi sifat Genetiknya Berdasarkan Analisa Isoenzim. [Thesis]. Program Pascasarjana, IPB, Bogor.

Smith SE, Smith FA, Jacobsen. 2003. Mycorrhizal fungi can dominate phosphate supply to pints irrespective of growth responses. Plant Physiol. 133, 16-20.

Toruan-Mathius, Rahmawati D, Anidah, Situmorang. 2007. Mikrografting In Vitro dan In Vivo Aquilaria malaccensis LAMK:: ANALISIS KOMPATIBILITAS. Laporan Akhir DIPA. 